\title{
THE CONCEPT OF (CRADLE TO CRADLE) THEORY IN THE DESIGN OF RECYCLED PRODUCTS
}

Marwa Muhammad Mustafa AL-MASRY *

${ }^{1}$ Faculty of Applied Arts, Helwan University, Egypt

\begin{abstract}
The environment is an integrated building that includes many elements that interact with each other according to a balanced system, and upon looking into this environment and its limited resources and the pollution to which it is exposed, we find that the world has set its sights on searching for alternatives that reduce the depletion of nature and energy consumption while creating new resources, and from them the concepts and applications concerned with developing recycling mechanisms to make optimal use of the waste of natural and industrial materials, and among these concepts is what is known as the concept of "Cradle to Cradle" which works on organizing the manufacturing process to prepare the product according to a system that can be recycled before starting to manufacture it, which in turn is in line with one of the most basic principles advocated by what is called (sustainability), which works to lay the foundations of the new environmental thought in a more profound and related way to nature, as well as achieving dependence on raw materials that do not negatively affect the environment through the possibility of recycling and reuse. Since the material is one of the elements of artistic creativity and design that has a great impact on highlighting the efficiency of the product, it was better for the designer to tend to the materials that contribute to preserving the environment and benefit from recycled products, which is what we are exposed to in the research through applying the concept of "Cradle to Cradle" in the framework of designing these products from the beginning to reach the possibility of recycling after the end of their cycle of use. Accordingly, the research is based on two axes, the first of which presents the concept of "the cradle to the cradle" and sheds light on the recycling process as the main axis of the concept of "Cradle to Cradle", and the second one presents the role of that concept in product design, especially the product made from recyclable materials.

Keywords

Concept, Cradle to Cradle, Recycling, Renovated Design, Recycled Materials.
\end{abstract}

\section{Introduction}

When looking at our stringent environmental conditions, our limited resources, and the pollution that our planet is exposed to on a daily basis, it was necessary for the designer to assume his responsibility towards the environment as a member of this society, by working in a way that protects and preserves the earth, therefore, the world's attention in the twentieth century turned to an interest in the theories of recycling in an attempt to search for ways to benefit from the residues and wastes resulting from the processes of agriculture and industry. this is through the integration between contemporary design theories and manufacturing technology in theoretical concepts and new applications of manufacturing, the most important of which is the concept of "Cradle to Cradle" which works to organize the manufacturing process to prepare the product and achieve the possibility of recycling it before its manufacture, in order to reduce the consumption of new resources and the optimal use of our limited resources, and to provide alternative materials that are low in costs that do not negatively affect

\footnotetext{
*Corresponding author: appliedarts@a-arts.helwan.edu.eg
} 
the environment, which is one of the most important basic principles that call for laying the foundations of the new environmental thought in a more profound and related way to nature.

\section{Research Problem}

- The prevalence of the design process of products without taking into account the problems which face the process of recycling after the end of their use cycle.

\section{Research Objectives}

- Set the concept of 'Cradle to Cradle' - as a key determinant of the design process for recyclable products.

\section{Research Hypothesis}

- Adopting the concept of "Cradle to Cradle" within the product design process reduces the obstacles that face the product in the process of recycling it.

\section{Research Methodology}

* The research follows the descriptive and analytical method in its theoretical framework

\section{The Concept of (Cradle to Cradle)}

The idea began when Robert Rodel developed a new agricultural system to take advantage of the farming as a whole. In the late 1950s, the architect "John Lail" endeavored to develop them to include all systems within the limits of renewable resources, and in the year 1995 the "Lyle Centre" worked with the architect "William Macdonough" to complete the environmental studies until the year 2000, so that the idea was further crystallized with the participation of "Macdonogh" with the German pharmacist "Michael Braungart" and the publication of their book "Cradle to Cradle" in 2002.

This term was coined by the architect "Walter R. Stahel" in the seventies of the twentieth century, meaning the full use of raw materials without waste from the beginning of the life cycle of the material to its end by transforming the concept from (take, make, leave or waste) into a concept. (Take, make, renew), within the system of developing its life cycle by taking advantage of the latest technologies and advanced technology, and accordingly this concept included three vital principles:

1. In nature there is no waste (waste means subsistence).

2. Create a new spirit.

3. Return the energy to its source.

This term is considered to be the opposite of the common phrase Cradle to Grave, meaning from "Birth to Death". The term "Cradle to Cradle" denotes what is sustainable and considerate for life and future generations, meaning that (From Birth to Birth again) that is 
from one generation to another.

\section{Conclusion}

Through the above, we find that the concept of "Cradle to Cradle" represents a paradigm shift in the process of product design in general, as the designer puts the design vision since the beginning of the design process, not just by looking at how the product is designed and manufactured - with its aesthetic and functional values - rather, his design vision extends beyond the end of the product use cycle and the conceptualization of recycling it which gives the product other values as an environmentally friendly product.

\section{Results}

1. The concept of "Cradle to Cradle" is easier to apply in the product design process than in the process of recycling after completing its use cycle.

2. The design process of products through recycled materials represents an exemplary application of the concept of "Cradle to Cradle".

\section{Recommendations}

The research recommends applying the concept of "Cradle to Cradle" in the product design process from the beginning of the initial design phase due to the success factors it represents and the ease of implementing the process of recycling these products after the end of their use cycle, which has a positive impact on the environment.

\section{References}

1. Andres R. Edward, David W. Orr: The Sustainability Revolution, Portrait of Paradigm, 2005.

2. Dearstyne-Howard- Inside the Bauhaus, 1986.

3. Han C. Brezet, Charles F. Hendrik, Allocation in Recycling Systems, An Integrated Model for the Analyses of Environmental Impact and Market Value, The International Journal of Life Cycle Assessment,2001.

4. Michael Braungart, William McDonough, Cradle to Cradle Remaking the Way we Make Things, North Point Press -Powell's book, 2002.

5. Sally Morgan: Waste, Recycling, Reuses, Evans Brothers Limited.2009

6. Steve Garner, Charles Evans, Design and Designing, Berg, UK, 2012.

7. Anna Marshall, Lisa Tucker, Cradle to Cradle Home Design, Fairchild Books, New York, 2012.

8. www.epa.gov

9. www.kireiusa.com/products/kirei-board

10. www.recycleyourplastics.org 
11. www.treehugger.com/eco

12. http://www.zerowaste.sa.gov.au/About-Us/waste-management-hierarchy

13. Faten Abdel Fattah Metwally ALI, STIMULATING SERIOUS POSITIVE INTERACTION BY CONFIRMING ITS DIMENSIONS AND MONITORING ITS ASPECTS OF CERAMIC DESIGNS, International Journal of Design and Fashion Studies, Vol. 2, No. 1, 2019, pp. 22-24.

Received: September 4, 2019

Accepted: November 13, 2019 